mentioned: Sir Benjamin Brodie's "Physiological Researches" (1851), Edwin Chadwick's "Report on the Sanitary Condition of the Labouring Population of Great Britain" (1843), A. Weismann's "Vorträge über Deszendenztheorie" (1904), first edition of Gray's "Anatomy" (1858), William Hamilton's "Observations on the Preparation, Utility and Administration of Digitalis Purpurea or Foxglove" (1807), Francis Home's "Medical Facts and Experiments" (1759), Hufeland's "Art of Prolonging Life" (1797), Lord Lister's "Contributions to Physiology and Pathology" (1859), Thomas Bateman's "Reports on the Diseases of London, and the State of the Weather from 1804 to 1816" (1819), Puschmann's "Handbuch der Geschichte der Medizin" (1902-1905), the first two volumes of Archiv für Physiologie (1796 -97 ) and a number of runs of the Lancet from 1848 until 1871.

\section{Recent Earthquakes}

DURING the third quarter of 1942 , the epicentres of ten strong earthquakes have been found chiefly from instrumental data from American observatories. The first four epicentres in July and August were determined at St. Louis by the Jesuit Seismological Association, and the others in August and September by the United States Coast and Geodetic Survey, in co-operation with the Jesuit Seismological Association and Science Service. On July 8 the epicentre was in Chile $\left(24 \cdot 5^{\circ} \mathrm{S} ., 69 \cdot 5^{\circ} \mathrm{W}\right.$.) with a depth of focus near $175 \mathrm{~km}$. A later earthquake on July 8 and one on July 12 had their epicentres near the coast of Ecuador $\left(0 \cdot 3^{\circ} \mathrm{S} ., 80 \cdot 2^{\circ} \mathrm{W}\right.$.) and a depth of focus near $500 \mathrm{~km}$. The latter was reported felt at Guayaquil. On August 6 the earthquake had its epicentre in the Pacific Ocean off the coast of Central America $\left(12 \cdot 9^{\circ}\right.$ N., $92 \cdot 1^{\circ}$ W. $)$. On August 23 a shock had its epicentre in the Pacific Ocean between the Kam. chatka Peninsula and the Aleutian Islands $\left(51.5^{\circ} \mathrm{N}\right.$, $163^{\circ}$ E.). Further shocks in the same region were on September $2\left(52.5^{\circ}\right.$ N., $170^{\circ}$ W.), September 4 $\left(52 \cdot 8^{\circ} \mathrm{N},{ }^{2}, 169 \cdot 2^{\circ} \mathrm{W}.\right)$, and September $9\left(53 \cdot 1^{\circ} \mathrm{N}\right.$., $165^{\circ} \mathrm{W}$.). Sequences of shocks in this manner are not uncommon and the present group is somewhat to the west of a similar group some months ago. The shock of August 24 had its epicentre near the coast of Peru $\left(14 \cdot 5^{\circ} \mathrm{S} ., 75 \cdot 5^{\circ} \mathrm{W}\right.$.) with a depth of focus between $50 \mathrm{~km}$. and $100 \mathrm{~km}$. A further earthquake with its epicentre in the Pacific Ocean off Central America $\left(12 \cdot 5^{\circ}\right.$ N., $91^{\circ}$ W.) occurred on September 4. On Thursday, October 29, an earthquake was felt in Western Turkey, including Istanbul and Smyrna. No damage has been reported.

\section{A New Comet}

A COMET was discovered by Oterma on Sept. 1ld. 23h. Its position at the time of discovery was R.A., 23h. 51m., Dec. $+6^{\circ} 20^{\prime}$, and its magnitude was 13. A later telegram announces that the comet was observed again on Nov. $6 \mathrm{~d} .20 \mathrm{~h} .16 \mathrm{~m}$., and its position then was R.A., $4 \mathrm{~h}$. $11 \mathrm{~m}$., Dec. $-0^{\circ} 47^{\prime}$. Its magnitude had not altered. It was stated to be moving slowly northward. An orbit will be computed when $a$ third position is obtained.

\section{The Night Sky in December}

New moon occurs on December 8 d. 01 h. $59 \mathrm{~m}$. U.T., and full moon on December 22d. 15h. $03 \mathrm{~m}$. Conjunctions during the month are as follows: Dec. 6d. 13h., Mars in conjunction with the moon, Mars $5^{\circ} \mathrm{S}$.; Dec. 20d. 17h., Saturn in conjunction with the moon, Saturn $3^{\circ}$ N.; Dec. 24d. 13h., Jupiter in conjunction with the moon, Jupiter $3^{\circ} \mathrm{N}$. Occultations of stars brighter than magnitude 6 are as follows, the times referring to Greenwich :

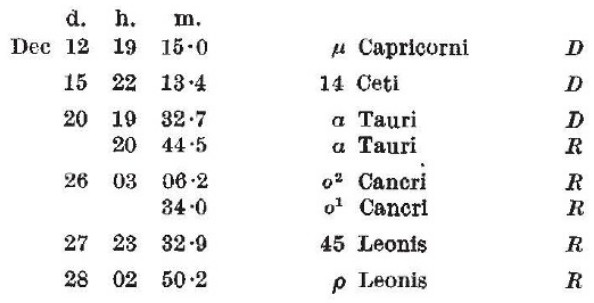

Mercury, Venus and Mars are not well placed for observation during the month. Jupiter, in Gemini, souths at $2 \mathrm{~h} .10 \mathrm{~m}$. about the middle of the month and is well placed for observation. Saturn, in Taurus, souths at $22 \mathrm{~h}$. $50 \mathrm{~m}$. in the middle of the month and can be observed all night. The Geminid meteor shower is active during December $7-15$, the radiant being close to $\alpha$ Geminorum. The winter solstice commences Dec. 22d. $12 \mathrm{~h}$.

\section{Announcements}

THE Minister of Supply has appointed Prof. J. E. Lennard-Jones, Plummer professor of theoretical chemistry in the University of Cambridge, to be chief superintendent of armament research, and Mr. F. E. Smith, of Imperial Chemical Industries, Ltd., to be chief engineer and superintendent of armament design. These appointments have resulted from the recommendations of a committee under the chairmanship of Dr. H. L. Guy recently appointed by the Minister of Supply to review the machinery for the conduct of research, design, and experimental work in connexion with the development of guns, small arms, and ammunition.

Dr. C. D. Darlington, director of the John Innes Horticultural Institution, has been invited to deliver lectures to the Mendelian Society of Lund in Sweden. $\mathrm{He}$ will journey to Sweden under the auspices of the British Council, and, in addition to his lectures at Lund, will speak on cytology to learned societies in other centres, and will also deliver a number of general lectures on a broad biological topic.

The Earl of Moray and Mr. J. M. Bannerman have been appointed members of the Forestry Commission in succession to Sir John Sutherland, who has submitted his resignation, and to fill another existing vacancy. At the request of the Secretary of State for Scotland, Sir John Sutherland has agreed to continue to attend meetings of the Commission so that his experience may be available when matters relating to Scotland are discussed.

The council of the Royal Meteorological Society has awarded the Buchan Prize for 1943 to Dr. T. E. W. Schumann and Mr. Gordon Manley. The Prize is awarded biennially to the authors of the papers published in recent issues of the Society's Quarterly Journal which have been adjudged to contain the most important original contributions to meteorology. 